\title{
Spatial taste formation as a place marketing tool: The case of live music consumption
}

Purpose - The aim of this paper is to explore how spatial taste formation and the interrelationships between place and taste can inform the development of contemporary place marketing and/or place management strategies.

Design/methodology/approach - The paper draws on previous research conducted within the context of live music consumption and, in particular, within live musical spaces such as festivals and concert halls.

Findings - Our study illustrates how spatial taste formation can inform the development of topographies of taste which focus on the creation of field-specific experiences. It also offers insights for understanding the phenomenological uniqueness of various places and the role of place users and other stakeholders in the creation of place marketing and branding value.

Originality/value - We elaborate upon the potential usefulness of spatial taste formation for place management and marketing research practice and draw out implications for future research. We advance a holistic and phenomenological understanding of place which illustrates how users' perceptions of place are shaped by their experiences in various places and by the interplay of these experiences with their individual tastes and vice versa.

Keywords: Place, Taste, Spatial taste formation, Place marketing, Live music consumption, Consumption experiences, Festivals, Concert halls

Paper type: Viewpoint 


\section{Introduction}

In a recent editorial in this journal, Medway et al. (2016) argue that place management and marketing researchers need to start taking into consideration the nature and meaning of the multi-sensorial experiences that individuals have in various places. Such experiences can lead to more complete and holistic understandings of place and prior research has already started to move in this direction (e.g. Henshaw et al., 2016; Medway, 2015; Warnaby and Medway, 2013), often through the adoption of phenomenological approaches to place which emphasise the totality of the physical, socio-cultural and historical meanings that unfold within specific spaces (Casey, 1997; Creswell and Hoskins, 2008; Malpas, 1999; Tuan, 1970). For instance, Henshaw et al. (2016) discuss the important role that city smells play in place distinctiveness and urban identity, through the creation of multi-sensory experiences based on the ambient smells of specific places.

The aim of this comment piece is to contribute to these emerging lines of research into place, by illustrating how study of the interrelationships between place and taste and the development of theories of spatial taste formation (Skandalis et al., 2015 ; 2016a; 2016b) can further inform contemporary place management and marketing strategies, opening up new avenues for future research. Our own previous research in the context of live music consumption demonstrated how musical taste formation in different musical places such as festivals and concert halls can be relevant and/or act as a place marketing tool for city/town authorities, place marketers and/or tourism professionals. Concerts and music festivals generated more than a third of global performing arts revenue in 2011 in Europe, and live music accounted 
for more than $£ 600 \mathrm{~m}$ in the UK economy in 2012 (EY, 2012; UK Music, 2013). We argue that spatial taste formation can lead towards more holistic thinking about how users' perceptions of place are affected by their live music experiences in different places, and by the interplay of these experiences with their individual tastes and vice versa.

In the following sections, we examine the potential usefulness of spatial taste formation as a place marketing tool and draw out the implications for future place marketing research. More specifically, we illustrate: how spatial taste formation can generate novel insights for the development of topographies of taste which foreground the creation of field-specific experiences; the phenomenological distinctiveness of specific places; and the role place users and other key stakeholders play in the creation of place marketing and branding value.

\section{Place, taste and live music consumption}

In the broader marketing literature, place has been predominantly conceptualised as a marketing mix element; a product of social interactions; and more recently, as a constituent of consumption practices ( $c f$. Skandalis et al., 2016a). In other words, place has been understood more as something that is subsumed to existing categories rather than as an active locus of meanings. Such materialistic conceptions of place often background the ontological qualities of place by leaving aside its lived dimensions which include a multitude of spatial subjectivities held by its various stakeholders. As Warnaby and Medway (2013) argue, contemporary place marketing approaches need to develop a holistic understanding of place as a dynamic concept, which is largely influenced by the construction of place narratives by different stakeholders. They suggest that 'there is potential for the reality of the place product and its representation to be more messy, incorporating the existence of a 
number of alternative spatial stories [...] more positive representations/portrayals of places, arising from the experience and memory of place users, can be capitalised upon to create a very potent place marketing tool' (Warnaby and Medway, 2013: 3567).

Here, place is conceptualised as something that is deeper than meaning and materiality and emerges along with individuals' embodied aesthetic experiences in different places. Such a phenomenological understanding considers place as a way of looking and knowing the world, as the experiential marker of our existence (e.g. Bachelard, 1964; Casey, 1998; Tuan, 1977). A phenomenological conception positions place as a platform of action that is physical and historical, social and cultural (Casey, 2001) and argues that we understand the world through our experiences in particular places (Tuan, 1977). As Edward Casey mentions 'there is no self without place and no place without self' (Casey, 2001: 686); place should be understood more as an event rather than a thing, and if we follow this understanding of place then it is valuable to explore the ontological significance of place and, for the purposes of this paper, to be able to investigate the interrelationships between place and taste.

To these ends, we introduced the concept of spatial taste formation as a useful place marketing tool that captures this messy and complex reality of places which arises through users' lived experiences in different spaces. In the context of live music consumption, we explored the interrelationships between place and taste in different music fields such as those of indie and classical music (Skandalis et al., 2016a; 2016b). For Bourdieu (1984), taste is achieved when individuals acquire different forms of capital (economic, social, cultural) through primary socialisation and their later participation and continuous involvement in various social fields that structure 
the social sphere (Bourdieu and Wacquant, 1992). By bringing together Bourdieu's theory of taste and phenomenological perspectives on space and place, we aimed to provide a more nuanced understanding of how consumers spatially enact, perform and further develop and shape their musical tastes in a given music field through their multi-sensory experiences in specific musical spaces such as the music festival (Skandalis et al., 2016b) or the concert hall (Skandalis et al., 2016a).

Prior research has fruitfully elaborated upon the variety of ways in which music is linked to and associated with a diverse range of musical spaces (Connell and Gibson, 2003; Halfacree and Kitchin, 1996; Fonarow, 2006; Gunn, 1997; Kruse, 1993). For example, Connell and Gibson (2003) have previously explored the interrelationships between music, identity and place and aimed to uncover the diverse meanings of music in a wide range of local contexts, scenes, and places. Such places can be approached and understood as platforms of action upon which musical tastes are shared and performed (Hennion, 2001; Thornton, 1996; Skandalis et al., 2016c). We argue that the study of the interrelationships between place and taste has the potential to shape and orchestrate future place marketing strategies; we illustrate this through the development of several examples in the following section. In exploring consumers' spatial development of musical knowledge and taste, several place marketing research objectives can be addressed and, following this, we also delve deeper into such research objectives and how they relate to place marketing research.

\section{The role of spatial taste formation in place marketing research}

In one of his key writings, the humanistic geographer and philosopher of place Yi Fu Tuan argued that '[w]e remain largely ignorant of the quality and range of experience in different types of physical settings under different conditions' (Tuan, 1977: 246). Such an argument is still valid today, especially within the place 
marketing literature where a complete understanding of users' multi-sensory experiences in various places is missing (Medway et al., 2016). Notable exceptions include exploration of the potential for place-specific multi-sensory experiences through the study of smell (Medway, 2015; Henshaw et al., 2016), sound (Oakes, 2000), and touch (Spence et al., 2014), amongst others.

Spatial taste formation can generate novel insights into the urban design and management of contemporary spaces and the delivery of user experiences that are aligned with their consumption practices, activities, and tastes. In the context of music consumption, spatial taste formation can help us to better understand what makes a city unique in terms of music consumption; develop insights into what makes urban 'music scenes'; and inform understandings of how urban policy initiatives can influence and capitalise on such understandings. Our previous research has illustrated that individuals accumulate different forms of field-specific capital through their place-dependent identity investments in festivals and concert halls which are embedded within the indie and classical music fields respectively (Skandalis et al., 2016a). In doing so, we have shown that the physical, socio-cultural, and historical meanings of these musical spaces have the potential to shape and transform individuals' tastes (Skandalis et al., 2016a; 2016b). In the context of classical music consumption, we found that classical music experiences in Manchester's Bridgewater Hall are largely shaped by the association of the concert hall with its predecessor (the Free Trade Hall); the classical music heritage of the city of Manchester; and the aural architecture of the concert hall itself. The Bridgewater Hall purposefully draws on these musical associations; located in Manchester's city centre, the square in front of the hall is named after Sir John Barbirolli (one of the most famous conductors of the Hallé orchestra) with his statue also featuring in front of the hall's entrance. The 
overall history of the place and the surrounding landscape were frequently mentioned by attendees as playing a major role in shaping their classical music experiences at the Bridgewater Hall (Skandalis et al., 2016a).

Place marketing strategies could employ such insights in order to foreground musical place distinctiveness and urban musical identity by providing detailed information about the physical, socio-cultural and historical meanings of places as part of the overall live music experience. In this sense, live music consumption has the potential to transcend the actual live music experience and to become associated with, and memorised in relation to, specific places.

Spatial taste formation studies might also open new avenues for segmenting and targeting consumers through the development of spatially-oriented segmentation strategies which can be extremely helpful for music places (e.g. venues) and cities to capitalise on their musical heritage, as well as on the cultural and creative dynamics of specific regions. Place marketers could usefully aim to develop topographies of taste in the creation and delivery of consumption experiences in the marketplace. A fruitful area of inquiry could be the extent to which various branded musical spaces interact and complement each other in the constitution of a spatial network of different music fields. Such topographies of taste can guide and orchestrate the experiential design of contemporary consumption spaces. For instance, place marketers could develop interactive websites and hard copy maps which illustrate and highlight the nature of field-specific live music experiences at a neighbourhood, region, and/or city level. Such a spatial visualisation of live music consumption could further enhance the attractiveness of specific places (e.g. sites of consumption such as venues and/or districts) and flesh out their unique distinctiveness. 
Accordingly, the strong and diverse musical heritage of certain cities such as Liverpool or Manchester can be utilised in order to orchestrate the design of urban landscapes which will be aesthetically oriented towards specific music fields and tastes. A good example is Manchester's Northern Quarter, a thriving cultural and creative hub in the city centre, which is aligned with the independent music industry and the indie music field (Skandalis et al., 2016c). Manchester has recently received more than $£ 200 \mathrm{~m}$ in cultural investment to fund the development of initiatives such as the HOME centre for international contemporary art or the Factory arts centre, yet large investments such as these can often be at the expense of smaller locally oriented arts projects (Walmsley, 2017). In this situation, spatial taste formation could be used to help highlight and maintain the unique selling propositions of specific places tied to the local grassroots level, such as Manchester's Northern Quarter, in order to ensure that when investing in arts and widening access, place marketing strategies can help to prevent cultural commodification and homogenisation (Karavatzis and Ashworth, 2008; Warnaby and Medway, 2013). Such research enquiries can also support local initiatives and/or civic movements such as the Manchester Shield, a recently formed user inspired civic movement, which aims 'to empower citizens in Manchester by promoting their collaboration in a better built environment \& city' (Manchester Shield, 2017). A museum dedicated to the music of Manchester, as has recently been called for (Lovell, 2017), would also assist in documenting the specific histories of the city's music scene.

Finally, through the adoption of a spatial taste formation perspective, place marketing research might delve deeper into the relationship between place branding and issues of taste. Research could potentially explore how aesthetic value is cocreated in musical spaces and may inform the development of effective place 
marketing strategies. For example, in an ongoing study we aim to capture how individuals accumulate place-dependent capital in the indie music field via their aesthetic experiences in a diverse range of musical spaces in Manchester (Skandalis et al., 2016c). The spatial attractiveness of various live music venues in Manchester is ultimately grounded in the historical antecedents of the indie music field in Manchester (see Robb 2009); from the early sounds of bands such as Joy Division, New Order, and The Smiths to the tunes of the Madchester era and the existence of local record labels and live music venues such as Factory Records and The Haçienda nightclub (Halfacree and Kitchin, 1996).

By emphasising this spatial attractiveness, Manchester has the potential to be further elevated and communicated as a significant place in the (global) indie music field. For instance, such research objectives can be achieved by building understandings of the role of consumers and key informants involved in the production of different forms of field-specific capital (e.g. music venue managers, promoters, and so on) and by further exploring how consumers' situated music experiences (e.g. in music venues) inform their developing musical knowledge and taste within the broader indie music field. In fact, the Manchester District Music Archive (https://www.mdmarchive.co.uk/), a user-led online website which was created to celebrate Greater Manchester's music and heritage and acts as a place in which people can share their musical memories of various live music venues in Manchester, can provide a useful platform to support such research enquiries. Future research might aim to investigate the role of spatial taste formation processes in place marketing and branding strategies. In doing so, the scope and breadth of place marketing strategies can be further expanded well beyond the tourism field (Karavatzis and Ashworth, 2008). 


\section{Conclusion}

The aim of this comment piece was to highlight the diversity of ways in which spatial taste formation approaches can inform contemporary place marketing strategies and open up new avenues for future place marketing research by drawing on the context of live music consumption and our own research conducted in this area. Live music experiences constitute a central aspect of individuals' music consumption and we have illustrated how spatial taste formation can be usefully employed as a place marketing tool in order to fully capture individuals' experiences in different places. We invite place marketing researchers and practitioners to explore further the potential usefulness of spatial taste formation for the development of contemporary place management strategies and embark upon future research efforts that lie at the intersection of the interrelationships between place and taste.

\section{References}

Bachelard, G. (1964), The Poetics of Space, Beacon Press, Boston, MA.

Bourdieu, P. (1984), Distinction: A Social Critique of the Judgement of Taste, Harvard University Press, Cambridge, MA.

Bourdieu, P. and Wacquant, L.J. (1992), An Invitation to Reflexive Sociology, University of Chicago Press, Chicago.

Casey, E. (1997), "Smooth spaces and rough-edged places: the hidden history of place", The Review of Metaphysics, Vol. 51 No. 2, pp. 267-296.

Casey, E. (1998), The Fate of Place: A Philosophical History, University of California Press Berkeley, CA. 
Casey, E. (2001), "Between geography and philosophy: what does it mean to be in the place-world?", Annals of the Association of American Geographers, Vol. 91 No. 4, pp. 683-693.

Connell, J. and Gibson, C. (2003), Soundtracks: Popular Music, Identity, and Place, Routledge, London.

Cresswell, T. and Hoskins, G. (2008), "Place, persistence, and practice: evaluating historical significance at Angel Island, San Francisco, and Maxwell Street, Chicago", Annals of the Association of American Geographers, Vol. 98 No. 2, pp. $392-413$.

EY (2014), "Creating growth: measuring cultural and creative markets in the EU", available at: http://www.ey.com/Publication/vwLUAssets/Measuring_cultural_and_creative_mark ets_in the_EU/\%24FILE/Creating-Growth.pdf (accessed 26 May 2017).

Fonarow, W. (2006), Empire of Dirt: The Aesthetics and Rituals of British Indie Music, Wesleyan University Press, Middletown, CT.

Gunn, T. (1997), “The sublime and the vulgar: the Hallé concerts and the constitution of 'high culture' in Manchester c. 1850-1880”, Journal of Victorian Culture, Vol. 2 No. 2, pp. 208-228.

Halfacree, K.H. and Kitchen, R.M. (1996), “'Madchester rave on': placing the fragments of popular music", Area, Vol. 28 No. 1, pp. 47-55.

Hennion, A. (2001), “Music lovers. Taste as performance”, Theory, Culture \& Society, Vol. 18 No. 5, pp. 1-22. 
Henshaw, V., Medway, D., Warnaby, G. and Perkins, C. (2016), "Marketing the 'city of smells"”, Marketing Theory, Vol. 16 No. 2, pp. 153-170.

Kavaratzis, M. and Ashworth, G. (2008), "Place marketing: how did we get here and where are we going?” Journal of Place Management and Development, Vol. 1 No. 2, pp. $150-165$.

Kruse, H. (1993), "Subcultural identity in alternative music culture", Popular Music, Vol. 12 No. 1, pp. 33-41.

Lovell, L. (2017), "Should Manchester have a music museum? How to get tickets for the Manchester Music Legacies Centre Debate”, Manchester Evening News, 22 February, available at: http://www.manchestereveningnews.co.uk/whats-on/musicnightlife-news/manchester-music-museum-debate-tickets-12638837 (accessed 29 May 2017).

Manchester Shield (2017), “Ambition \& ethos - A user inspired civic movement that seeks to empower citizens in Manchester by promoting their collaboration in a better built environment \& city", available at: http://mcrshield.co.uk (accessed 30 May 2017).

Malpas, J. (1999), Place and Experience: A Philosophical Topography, Cambridge University Press, Cambridge.

Medway, D. (2015), "Place branding and the 'other' senses", in Kavaratzis, M., Warnaby, G. and Ashworth, G.J. (Eds.), Rethinking Place Branding: Comprehensive Brand Development for Cities and Regions, Springer, Heidelberg, pp. 191-209.

Medway, D., Parker, C., Quin, S. and Roberts, G. (2016), “Changing places; placing change", Journal of Place Management and Development, Vol. 9 No. 1. 
Oakes, S. (2000), "The influence of the musicscape within service environments", Journal of Services Marketing, Vol. 14 No. 7, pp. 539-556.

Robb, J. (2009), The North Will Rise Again: Manchester Music City 1976-1996, Aurum Press, London.

Skandalis, A., Banister, E. and Byrom, J. (2015), "Toward a spatial theory of taste formation", NA-Advances in Consumer Research, Vol. 43, pp. 404-408.

Skandalis, A., Banister, E. and Byrom, J. (2016a), "Marketplace orchestration of taste: insights from the Bridgewater Hall", Journal of Marketing Management, Vol. 32 Nos. 9-10, pp. 926-943.

Skandalis, A., Banister, E. and Byrom, J. (2016b), “The spatial aspects of musical taste: conceptualising consumers' place-dependent identity investments", Marketing Theory (forthcoming).

Skandalis, A., Banister, E. and Byrom, J. (2016c), "Musical taste and the creation of place-dependent capital: reflections from the indie music field", paper presented at the Consumer Culture Theory Conference, 6-9 July, Lille, France.

Spence, C., Puccinelli, N. and Grewal, D. (2014), "Store atmospherics: a multisensory perspective", Psychology and Marketing, Vol. 31 No. 7, pp. 472-488.

Thornton, S. (1996), Club Cultures: Music, Media and Subcultural Capital, Polity Press, Cambridge.

Tuan, Y.-F. (1977), Space and Place: The Perspective of Experience, University of Minnesota Press, Minnesota. 
UK Music (2013), "The economic contribution of the core UK music industry: summary report", available at: http://www.ukmusic.org (accessed 7 January 2017).

Walmsley, B. (2017). "Will Manchester's cultural boom benefit the whole of the North?", Apollo: The International Art Magazine, available at: https://www.apollomagazine.com/will-manchesters-cultural-boom-benefit-whole-north/ (accessed 1 May 2017).

Warnaby, G. and Medway, D. (2013), "What about the 'place' in place marketing?", Marketing Theory, Vol. 13 No. 3, pp. 345-363. 